\title{
Potential for Increasing Soil Nutrient Availability via Soil Organic Matter Improvement Using Pseudo Panel Data
}

\author{
María Daniela Chavez ${ }^{*}$, Paulus Bernardus Maria Berentsen², Oene Oenema ${ }^{3}$, \\ Alfons Gerard Joseph Maria Oude Lansink ${ }^{2}$ \\ ${ }^{1}$ Instituto Nacional de Tecnología Agropecuaria (INTA), Estación Experimental Salta, Grupo de Estudios \\ Económicos y Sociología Rural, Cerrillos (Salta), Argentina \\ ${ }^{2}$ Business Economics Group, Department of Social Sciences, Wageningen University, Wageningen, \\ The Netherlands \\ ${ }^{3}$ Soil Quality, Environmental Sciences Group, Wageningen University, Wageningen, The Netherlands \\ Email: chavez.daniela@inta.gob.ar
}

Received 6 May 2014; revised 23 June 2014; accepted 21 July 2014

Copyright (C) 2014 by authors and Scientific Research Publishing Inc. This work is licensed under the Creative Commons Attribution International License (CC BY). http://creativecommons.org/licenses/by/4.0/ (c) (i) Open Access

\section{Abstract}

Fixed and random effect models were applied to a pseudo-panel data built of soil analysis reports from tobacco farms to analyze relationships between soil characteristics like soil organic matter (SOM) and soil nitrogen (N), phosphorous (P) and potassium (K) and to explore the potential for improving nutrients availability by increasing SOM content. These econometric models may account for unobserved specific characteristics such as location-specific characteristics, management strategies, farmers' skills and preferences and environmental heterogeneity. Positive relationships were found between $\mathrm{N}, \mathrm{P}$ and $\mathrm{K}$ availability and SOM. The random effect model reports a highly significant elasticity of $\mathrm{N}$ with respect to SOM of 0.75 , meaning that an increase of $1 \%$ of SOM will increase soil $\mathrm{N}$ by $0.75 \%$. Using this elasticity, the required SOM improvement of green manure was calculated at which costs of green manure would exactly equal benefits in terms of reduced $\mathrm{N}$ fertilizer use. Costs and benefits are equal if the SOM increases from $1.55 \%$ to $3.61 \%$, which is barely achieved according to the literature. Hence, growing green manure crops to increase SOM and thereby $\mathrm{N}$ availability is not economically attractive. However, additional benefits may arise from SOM improvement and growing green manure crops.

\section{Keywords}

Soil Degradation, Fixed and Random Effects, SOM Improvement Benefits and Costs, Green Manure

\footnotetext{
${ }^{*}$ This article is part of the PhD thesis entitled exploring opportunities for diversification of specialized tobacco farms in the Northwest of Argentina (Wageningen University). The article was presented in the 1st National Meeting of Agricultural Economics and Rural Extension, October 2010, San Luis, Argentina.

How to cite this paper: Chavez, M.D., Berentsen, P.B.M., Oenema, O. and Oude Lansink, A.G.J.M. (2014) Potential for Increasing Soil Nutrient Availability via Soil Organic Matter Improvement Using Pseudo Panel Data. Agricultural Sciences, 5, 743-753. http://dx.doi.org/10.4236/as.2014.58078
} 


\section{Introduction}

Soil degradation can be a consequence of erosion, soil nutrient depletion, soil organic matter (SOM) decline, soil pollution, salinization and/or a collapse in soil structure [1]-[3]. SOM is commonly seen as an important indicator of soil productivity. It is a reserve of nutrients, and helps the formation of soil aggregates, enhances soil porosity, increases the water holding capacity and cation exchange capacity, improves root growth, and it activates soil biota development [1] [4]-[7]. Soil degradation ultimately leads to a decline of soil productivity. Crop yields tend to decrease and the incidence of a complete crop failure tends to increase when soils become more degraded.

The research reported here, was motivated by the observation that soils devoted to tobacco (Nicotiana tabacum L.) production in the Valle de Lerma in Salta province (Argentina) showed signs of degradation after almost 70 years of continuous tobacco production [8]. Tillage, improper water and nutrient management and absence of crop rotations have been suggested as main reasons for soil degradation [9] [10]. Soils under tobacco show 60 percents less SOM than soils under 40-year-old forests in the same area. Low SOM content has been implicated for poor soil structure, low nitrogen availability, poor soil aeration and soil compaction. The utilization efficiency of applied nitrogen $(\mathrm{N})$, phosphorus $(\mathrm{P})$ and potassium $(\mathrm{K})$ is low and farmers have increased the application of fertilizers in the last years, to be able to maintain productivity [11] [12].

Experiments are broadly applied to study relationships between nutrients availability and soil characteristics and management practices [13]-[15]. Also, effect of management practices on SOM have been well-addressed [5] [6] [16] [17], in part on the basis of simulation models [1] [18]. What remains short is quantitative information on the influence of SOM level on nutrient availability in farmers' field and on economic aspects of increasing SOM. This empirical study adds a novel approach on the analysis of soil nutrient availability by applying econometric models to analyze farmers' field data, and by using the established relation to determine economics of SOM improvement through green manure. To our knowledge an assessment of the economic impacts of changes on SOM has not been reported before. Studies usually reveal the importance of SOM in increasing crop yields but do not provide cost-benefits analyses of measures to improve SOM [17] [19]-[21].

An ordinary panel data set includes repeated observations of the same unit of observation (firms, individuals) collected over a number of periods [22] [23]. However, panel data are not available for this research. As an alternative, we construct pseudo panel data for statistical analysis, meaning that observations of different years and different farms are aggregated into groups (cohorts). The averages per year of the groups are treated as individual observations which are followed over time [24]-[26]. Applications include research on transportation and on farm household consumption [25] [26].

The first aim of this study was to get insight in the current SOM content in farmers' fields in the Valle de Lerma. The second aim was to analyze relationships between soil characteristics like SOM and soil N, P and K to explore the potential for improving nutrients availability by increasing SOM content. The third aim was to estimate the required level of SOM improvement by means of green manure that would be required to make green manure an economically feasible option for SOM improvement.

\section{Materials and Methods}

\subsection{Study Area}

The Valle de Lerma (between $24^{\circ} 30^{\prime} \mathrm{S}$ and $25^{\circ} 38^{\prime} \mathrm{S}$, and $65^{\circ} 22^{\prime} \mathrm{W}$ and $65^{\circ} 37^{\prime} \mathrm{W}$ ) is a plain with a temperate climate and an annual rainfall between 500 and $1000 \mathrm{~mm}$. Tobacco is cultivated on irrigated land [27] [28]. Besides tobacco, bean, corn, vegetables, pastures, fruits, beef and dairy are produced in the region. Tobacco is a highly fertilized with a dosage of 600 to $1000 \mathrm{~kg}$ NPK per ha. Soils have a loamy texture in $60 \%$, sandy loam in $20 \%$ and silt loam in $20 \%$ of the area [29]. Soils under tobacco are tilled to allow a good development of plants roots. However, the excessively tilling and mechanical weeding that is found in the region (12 or more operations in a year) contributes to soil degradation [10] [12] [30].

\subsection{Data Acquisition}

Data were analyzed from three departments (Cerrillos, Chicoana and Rosario de Lerma), which together produce $73 \%$ of the tobacco in Salta province [31]. Here, $90 \%$ of the farms producing tobacco are specialized tobacco farms [32].

The data were derived from 311 soil analysis reports from farms producing tobacco. Those reports cover the 
period 1999 to 2009. The soil analyses have been made by the Laboratory of the National Institute for Agricultural Technology [33] on requests by farmers and professionals to get a diagnosis of the soil fertility status in the upper 20 - $25 \mathrm{~cm}$ of the soil [30]. Unfortunately, no field-specific information was available about the number of years of tobacco production and management practices.

Total $\mathrm{N}$ was determined by Kjeldahl method. Extractable P was determined by Bray and Kurtz method. Carbon (C) was determined by the procedure proposed by Walkley and Black method. To estimate SOM, the C content was multiplied by 1.724 (Van Bemmelen factor), assuming that SOM contains 58\% C. Texture was determined by Bouyoucos. The exchangeable cations $\mathrm{K}$, calcium $(\mathrm{Ca})$, magnesium $(\mathrm{Mg})$ and sodium $(\mathrm{Na})$ were determined following ammonium acetate extraction. The $\mathrm{pH}$ was determined in paste [34].

\subsection{Pseudo Panel Data}

Analyzing panel data would be useful to address the problem at hand, because panel data provides the cross-sectional information reflected in differences in nutrient availability and SOM content between farms and time-series or within-subject information reflected in the changes in nutrient availability and SOM content within farms over time [35]. Because panel data are not available, observations of different years and different farms are aggregated into groups (cohorts) to construct a pseudo panel data. The cohorts need to have time invariant characteristics and observations should be homogeneous within cohorts and heterogeneous across cohorts [26].

The geographic area and soil textural class are used to create the cohorts. Reports were sorted following soil textural class. Then, reports concerning a particular texture were grouped by farm (every time it was possible), or the same region or the same department. So each cohort is a farm, a region or a department for which at least two year of data is available. When more than one report was available for the same year and cohort, the average was included as one observation for that cohort and year. When a cohort had only one year of observations it was discarded, since panel data techniques require at least two observations from one cohort. In total 70 cohorts and 190 observations were included in the data set. In Appendix (Table A1) the number of cohorts by textural classes and departments are displayed. The descriptive statistics for all the variables included in the study are displayed in Table 1 .

Mean SOM content is low ( $<10$ g per $\mathrm{kg}$ of $\mathrm{C}$ ), Total $\mathrm{N}$ is somewhat limited and extractable $\mathrm{P}$ and exchangeable $\mathrm{K}$ is relatively high. Soil $\mathrm{pH}\left(\mathrm{H}_{2} \mathrm{O}\right)$ is neutral, while extractable $\mathrm{Ca}, \mathrm{Mg}$ and Na seem not limiting crop growth [36].

\section{Table 1. Cohort descriptive statistics of selected variables.}

\begin{tabular}{|c|c|c|c|c|c|c|}
\hline Variables & Units & Mean & Median & Std. dev. & Min & Max \\
\hline SOM & $\%$ & 1.55 & 1.48 & 0.37 & 0.61 & 2.31 \\
\hline Sand (particles $>50 \mu \mathrm{m})(\mathrm{Sa})$ & $\%$ & 44 & 44 & 12 & 18 & 73 \\
\hline Clay (particles < $2 \mu \mathrm{m}$ ) (Cl) & $\%$ & 19 & 18 & 7 & 7 & 56 \\
\hline Silt (particles 2 - $50 \mu \mathrm{m})(\mathrm{Si})$ & $\%$ & 37 & 38 & 7 & 20 & 53 \\
\hline Total $\mathrm{N}(\mathrm{N})^{\mathrm{a}}$ & $\%$ & 0.10 & 0.10 & 0.02 & 0.05 & 0.14 \\
\hline Extractable P (P) & $\mathrm{mg} \cdot \mathrm{kg}^{-1}$ & 25.2 & 24.5 & 10.1 & 8.0 & 53.3 \\
\hline Exchangeable K (K) & $\mathrm{mmol}_{\mathrm{c}} \cdot \mathrm{kg}^{-1}$ & 8.7 & 7.5 & 4.5 & 3.4 & 25 \\
\hline $\mathrm{pH}\left(\mathrm{H}_{2} \mathrm{O}\right)$ & - & 6.95 & 6.98 & 0.64 & 5.65 & 8.30 \\
\hline $\mathrm{C} / \mathrm{N}$ & - & 9.2 & 9.1 & 1.0 & 5.5 & 12.5 \\
\hline Exchangeable Calcium (Ca) & $\mathrm{mmol}_{\mathrm{c}} \cdot \mathrm{kg}^{-1}$ & 70.3 & 61.9 & 23.5 & 41.0 & 136.0 \\
\hline Exchangeable Magnesium (Mg) & $\mathrm{mmol}_{\mathrm{c}} \cdot \mathrm{kg}^{-1}$ & 19.3 & 19.5 & 5.9 & 8.5 & 40.0 \\
\hline Exchangeable Sodium (Na) & $\mathrm{mmol}_{\mathrm{c}} \cdot \mathrm{kg}^{-1}$ & 5.4 & 5.0 & 2.1 & 2.0 & 13.9 \\
\hline Water saturation (Ws) & $\%$ & 29.8 & 29.1 & 4.6 & 21.7 & 42.0 \\
\hline
\end{tabular}

${ }^{\mathrm{a}}$ Total $\mathrm{N}$ represents the amounts of organic and ammonium nitrogen; ${ }^{\mathrm{b}}$ Water needed to saturate $100 \mathrm{~g}$ of dried soil. 


\subsection{Econometric Models}

Fixed and random effects models were used to assess factors influencing $\mathrm{N}, \mathrm{P}$ and $\mathrm{K}$ availability. The random effect model provides more efficient parameter estimates (low standard errors) than the fixed effect model, but it assumes that the individual effects are uncorrelated with regressors [37] [38]. If this condition is violated, parameter estimates of the random effect model are not consistent. In that case, the parameter estimates of the fixed effects model are still consistent, though less efficient [38].

The formulation of the fixed effect model assumes that differences across cohorts can be captured in differences in the constant [37]. The theoretical form of the fixed effect model is as follows:

$$
y_{i t}=\alpha_{i}+\beta x_{i t}+\varepsilon_{i t}
$$

where $y_{i t}$ is the dependent variable, namely $\mathrm{N}, \mathrm{P}$ and $\mathrm{K}$ contents for cohort $i$ in year $t, x_{i t}$ is a vector of explanatory variables for the cohort $i$ in year $t$, and $\beta$ is the coefficient for explanatory variables. The $\alpha_{i}$ is the intercept for each cohort and it captures the effect of those variables that are specific for the $i$-th cohort, they are constant over time and they are consider as fixed unknown parameters. Finally, $\varepsilon_{i t}$ is assumed to be independent and identically distributed over individuals and time, with mean zero and variance $\sigma_{\varepsilon}^{2}$ [23] [39].

The random effect model assumes that the individual effects, the intercepts of cohorts, are different but they are considered as random, with mean $\mu$ and variance $\sigma_{\alpha}^{2}$.The theoretical model is as follows:

$$
y_{i t}=\mu+\beta x_{i t}+\alpha_{i}+\varepsilon_{i t}
$$

Where $y_{i t}$ is the dependent variable, namely $\mathrm{N}, \mathrm{P}, \mathrm{K}$ for cohort $i$ in year $t, \mu$ is the intercept term and it represents the mean of the unobserved heterogeneity, $x_{i t}$ is a vector of explanatory variables for the cohort $i$ in year $t$ and $\beta$ is the coefficient for explanatory variables. The error term consists of two components: a time invariant component $\alpha_{i}$ that accounts for heterogeneity specific to the ith cohort (cross-section specific error) and a remainder component $\varepsilon_{i t}$ that is uncorrelated over time [22] [23] [37] [38].

A Hausman test was performed to test the random effects model versus the fixed effects model [23]. If the individual effects are correlated with the regressors, then the Hausman test rejects the random effects model. Because of its simplicity, a log-log linear function is used in this research. In addition to the fixed effect model, a least square dummy variable model (LSDV) can be run, to get the particular effect of each cohort [39].

\subsubsection{Nitrogen}

The general specification of the model for nitrogen for a log-linear function is as follows:

$$
\log _{\mathrm{e}} y_{N}=a_{0 N}+\sum_{i=1}^{k} \alpha_{i N} \log _{\mathrm{e}} x_{i}+\varepsilon_{N}
$$

where $\log _{e} y_{N}$ is the natural $\operatorname{logarithm}$ of total soil $\mathrm{N}$; $\log _{\mathrm{e}} x_{i}$ are the natural logarithms of the $k$ variables, namely $\mathrm{SOM}, \mathrm{pH}$, clay $(\mathrm{Cl})$, silt $(\mathrm{Si})$ particles and a time trend (tt) variable. This time trend variable is included to reflect technological and management change; $\alpha_{0 N}, \alpha_{i N}, i=1,2, \ldots k$ are parameters; $\varepsilon_{N}$ is the error term.

\subsubsection{Phosphorus}

The general specification of the model for $\mathrm{P}$ for a log-log linear function is as follows:

$$
\log _{\mathrm{e}} y_{P}=a_{0 P}+\sum_{i=1}^{k} \alpha_{i P} \log _{\mathrm{e}} x_{i}+\varepsilon_{P}
$$

where $\log \mathrm{y}_{P}$ is the natural logarithm of extractable $\mathrm{P}$; $\log _{\mathrm{e}} \mathrm{x}_{i}$ are natural logarithms of the $k$ variables, namely SOM, $\mathrm{pH}$, saturation water (Ws), clay $(\mathrm{Cl})$, calcium $(\mathrm{Ca})$, sodium $(\mathrm{Na})$ and a time trend (tt) variable. This time trend variable is included to reflect technological and management change; $\alpha_{0 P}, \alpha_{i P}, i=1,2, \ldots k$ are parameters; $\varepsilon_{P}$ is the error term.

\subsubsection{Potassium}

The general specification of the model for $\mathrm{K}$ for a log-linear function is as follows:

$$
\log _{\mathrm{e}} y_{K}=a_{0 K}+\sum_{i=1}^{k} \alpha_{i K} \log _{\mathrm{e}} x_{i}+\varepsilon_{K}
$$


where $\log _{\mathrm{e}} y_{K}$ is the natural logarithm of exchangeable $\mathrm{K} ; \log _{\mathrm{e}} x_{i}$ are the natural logarithms of the $k$ variables, namely SOM, pH, clay (Cl), water saturation (Ws), calcium (Ca) content, magnesium (Mg) content and a time trend (tt) variable. This time trend variable is included to reflect technological and management change; $\alpha_{0 K}, \alpha_{i K}$, $i=1,2, k$ are parameters; $\varepsilon_{K}$ is the error term.

STATA 10.1 software was used to run the models [40].

\subsection{Analyses of Benefits and Costs of SOM Improvement through Green Manure}

One simple way to increase SOM may be to grow a green manure crop after tobacco harvest at the end of summer time and beginning of autumn. Green manure relates to the incorporation of fresh plant tissue into the soil [41]. By growing green manure the soil is kept covered in winter time and it does not compete with tobacco for land; at the end of winter the green manure can be incorporated to the soil before tobacco plantation starts. Possible green manure crops in the area include the following winter crops: wheat, barley, oat, rye and triticale [42].

Improvement of SOM might mean a higher soil nutrient availability (this is to be confirmed by the econometric model) leading to economic benefits because of lower fertilization requirements. So, benefits of SOM improvement refer to costs savings in commercial fertilizers. To calculate those cost savings, three effects need to be known: 1) the effect of growing a green manure crop on SOM; 2) the effect of increasing SOM on N, P, and $\mathrm{K}$ availability, and 3) the effect of increased soil N, P, and K availability on the required amount of fertilizer.

Long terms experiments are required to assess the effect of growing green manure on SOM improvement. In this study, we estimated the necessary SOM improvement by green manure to be economically feasible because data of the effect of growing a green manure on SOM is not available for the area.

The effect of increasing SOM on soil N, P and $\mathrm{K}$ is given by the elasticity of N, P and K with respect to SOM, which was estimated by the econometric models. The effect of increased soil N, P, and $\mathrm{K}$ on the required amount of fertilizer is specific for each nutrient. The functions that relate $\mathrm{N}, \mathrm{P}, \mathrm{K}$ fertilizer necessary for tobacco production to changes in soil N, P and $\mathrm{K}$ were derived from data of [43]. It takes a quadratic form for $\mathrm{N}$ and a lineal form for $\mathrm{K}$ and $\mathrm{P}$ :

$$
y_{N F}=52-118 x_{T N}-200 x_{T N}^{2}
$$

where $y_{N F}$ is $\mathrm{N}$ fertilizer, in kg per ha, required for tobacco production, and $x_{T N}$ is soil $\mathrm{N}$, in $\%$.

$$
y_{P F}=93-1.8 x_{E P}
$$

where $y_{P F}$ is $\mathrm{P}$ fertilizer, in kg per ha, required for tobacco production, and $x_{E P}$ is extractable $\mathrm{P}$, in $\mathrm{mg} / \mathrm{kg}$. For $x_{E P}$ larger than $20 \mathrm{mg} \cdot \mathrm{kg}^{-1}, y_{P F}$ takes the value of $60 \mathrm{~kg}$.

$$
y_{K F}=127-9 x_{E K}
$$

where $\mathrm{y}_{K F}$ is $\mathrm{K}$ fertilizer, in $\mathrm{kg}$ per ha, required for tobacco production, and $x_{E K}$ is exchangeable $\mathrm{K}$, in $\mathrm{mmol}_{\mathrm{c}} \cdot \mathrm{kg}^{-1}$. For $x_{E K}$ larger than $8 \mathrm{mmol}_{\mathrm{c}} \cdot \mathrm{kg}^{-1}, y_{K F}$ takes the value of $60 \mathrm{~kg}$.

The common NPK fertilizer in the Valle de Lerma is the compound 11-17-24 [30], indicating that $100 \mathrm{~kg}$ of fertilizer contains $11 \mathrm{~kg}$ of $\mathrm{N}, 17 \mathrm{~kg}$ of $\mathrm{P}_{2} \mathrm{O}_{5}$ and $24 \mathrm{~kg}$ of $\mathrm{K}_{2} \mathrm{O}$. The price was US\$ 780 per ton [44]. Labor costs for fertilizer application was estimated at around 25.25 US\$ per $300 \mathrm{~kg}$ of fertilizer.

Costs of SOM improvement refer to yearly variable costs of green manure crops. These costs include seeds, gasoil, labor and machinery maintenance. Technical data to estimate variable costs of green manure crops were obtained from [45] [42] and local experts. Variable costs of these crops were estimated at 140 US\$/ha and include one irrigation event (1 US\$ = 3.96 Argentinian pesos). The cost of green manure of 140 US\$ per ha equals the value of $162 \mathrm{~kg}$ of $11-17-24$ commercial fertilizer (including fertilizer price and application cost), which is equivalent to $17.8 \mathrm{~kg} \mathrm{~N}$ fertilizer.

\section{Results}

\subsection{Econometric Models}

Tables 2-4 show the parameter estimates for the fixed and random effects models that were not rejected by the Hausman test. For the log-linear function the elasticity is given by each parameter coefficient. 
Table 2. Parameter estimates of the random effect model for Nitrogen.

\begin{tabular}{|c|c|c|c|c|}
\hline Parameter & Coefficient & Std. Error & $Z$ & $\mathbf{P}>\mathbf{z}$ \\
\hline SOM & 0.75 & 0.03 & 23.18 & $0.000^{* *}$ \\
\hline $\mathrm{pH}$ & -0.11 & 0.10 & -1.12 & 0.264 \\
\hline $\mathrm{Si}$ & 0.03 & 0.05 & 0.52 & 0.603 \\
\hline $\mathrm{Cl}$ & 0.01 & 0.03 & 0.17 & 0.868 \\
\hline $\mathrm{tt}$ & -0.01 & 0.02 & -0.51 & 0.609 \\
\hline Intercept & -2.52 & 0.27 & -9.26 & $0.000^{* *}$ \\
\hline & \multicolumn{4}{|c|}{ R-sq (overall) $=0.7864$} \\
\hline & \multicolumn{4}{|c|}{ Wald chi square $(5)=635.04 .21$ Prob $>$ chi square $=0.0000$} \\
\hline & \multicolumn{4}{|c|}{ Rho $=0.246$} \\
\hline
\end{tabular}

Notes: Number of observations $=190$. Number of cohorts $=70$; Significantly different from zero at ${ }^{* *} 5 \%$ level; SOM $=$ soil organic matter; $\mathrm{pH}$ = level of acidity or alkalinity; $\mathrm{Si}$ = silt; $\mathrm{Cl}$ = clay; $\mathrm{tt}$ = time trend.

Table 3. Parameter estimates of the random effects models for Phosphorus.

\begin{tabular}{|c|c|c|c|c|}
\hline Parameter & Coefficient & Std. Error & $Z$ & $\mathbf{P}>\mathbf{z}$ \\
\hline SOM & 0.25 & 0.17 & 1.53 & 0.127 \\
\hline $\mathrm{pH}$ & -0.89 & 0.45 & -1.98 & $0.047^{* *}$ \\
\hline $\mathrm{Na}$ & -0.27 & 0.07 & -3.73 & $0.000^{* *}$ \\
\hline Ws & -1.17 & 0.45 & -2.61 & $0.009^{* *}$ \\
\hline $\mathrm{Cl}$ & 0.24 & 0.17 & 1.39 & 0.166 \\
\hline $\mathrm{tt}$ & -0.19 & 0.09 & -2.08 & $0.037^{* *}$ \\
\hline Intercept & 8.75 & 1.26 & 6.92 & $0.000^{* *}$ \\
\hline & \multicolumn{4}{|c|}{ R-sq (overall) $=0.2009$} \\
\hline & \multicolumn{4}{|c|}{ Wald chi square $(6)=43.22$ Prob $>$ chi square $=0.0000$} \\
\hline & \multicolumn{4}{|c|}{ Rho $=0.132$} \\
\hline
\end{tabular}

Notes: Number of observations $=186$. Number of cohorts $=70$; Significantly different from zero at ${ }^{* *} 5 \%$ level; SOM $=$ soil organic matter; $\mathrm{pH}$ = level of acidity or alkalinity; $\mathrm{Na}=$ sodium; $\mathrm{Ws}=$ water saturation; $\mathrm{Cl}=$ clay; $\mathrm{tt}=$ time trend.

\subsubsection{Nitrogen}

The Hausman test (chi square $=1.02, \operatorname{Pr}=0.9607)$ suggests that the random effects model was appropriate for explaining variation in $\mathrm{N}$. The overall R-squared $(0.78)$ is high. SOM content is the only variable with a significant effect; the positive elasticity of 0.75 suggests that an increase of SOM increases soil $\mathrm{N}$. The intercept suggests that there are negative and significant cohorts' specific effects on $\mathrm{N}$ availability. The value of rho suggests that almost $25 \%$ of the variability in $\mathrm{N}$ was due to differences in cohorts' specific effects.

\subsubsection{Phosphorus}

The Hausman test (chi square $=3.71, \mathrm{Pr}=0.7165$ ) suggests that the random effect estimator is consistent and is appropriate for explaining variation in $\mathrm{P}$ availability. SOM had a positive effect on $\mathrm{P}$, although the effect is not significant at $5 \%$. Notably, $\mathrm{pH}$ shows a negative effect on extractable $\mathrm{P}$. The negative elasticity of $\mathrm{pH}$ is consistent with results obtained in alkaline soils, where $\mathrm{P}$ uptake is negatively influenced by $\mathrm{pH}$ [46]. Exchangeable 
Table 4. Parameter estimates of the fixed effects models for Potassium.

\begin{tabular}{|c|c|c|c|c|}
\hline Parameter & Coefficient & Robust Std. Error & $t$ & $\mathrm{P}>|t|$ \\
\hline SOM & 0.31 & 0.23 & 1.34 & 0.18 \\
\hline $\mathrm{pH}$ & 1.04 & 0.67 & 1.54 & 0.13 \\
\hline Ws & -0.08 & 0.58 & -0.13 & 0.90 \\
\hline $\mathrm{Cl}$ & 0.31 & 0.18 & 1.66 & 0.10 \\
\hline $\mathrm{tt}$ & 0.28 & 0.09 & 2.99 & $0.004^{* *}$ \\
\hline Intercept cohort 39 & 0.85 & 0.35 & 2.44 & $0.016^{* *}$ \\
\hline Intercept cohort 40 & 0.80 & 0.37 & 2.16 & $0.033^{* *}$ \\
\hline Intercept cohort 48 & 1.27 & 0.43 & 2.93 & $0.004^{* *}$ \\
\hline Intercept cohort 49 & 1.15 & 0.40 & 2.90 & $0.005^{* *}$ \\
\hline Intercept & -1.28 & 2.00 & -0.64 & 0.525 \\
\hline & & sq (overall) $=0.27$ & & \\
\hline \multicolumn{5}{|c|}{$F(5,69)=6.54$ Prob $>F=0.0000$} \\
\hline \multicolumn{5}{|c|}{ Rho $=0.44$} \\
\hline
\end{tabular}

Notes: Number of observations $=190$. Number of cohorts $=70$; Significantly different from zero at ${ }^{* *} 5 \%$ level; SOM $=$ soil organic matter; $\mathrm{pH}=$ level of acidity or alkalinity; $\mathrm{Ws}=$ water saturation; $\mathrm{Cl}$ = clay; $\mathrm{tt}=$ time trend.

Na was negatively related to $\mathrm{P}$ availability, in agreement with results that show a decreased $\mathrm{P}$ uptake when salinity is increased [47]. The negative elasticity of water saturation is the opposite of what is expected a priori. A negative effect of the time trend variable indicates that there has been a decrease of $\mathrm{P}$ availability over time. This reduction can be explained by the changes in fertilizer formulation (with lower $\mathrm{P}$ content) that has been taking place in the last years [48]. The intercept suggests that there are positive and significant cohorts' specific effects on $\mathrm{P}$ availability. The value of rho indicates that $13 \%$ of $\mathrm{P}$ variability is due to differences in cohorts' specific effects.

\subsubsection{Potassium}

The Hausman test (chi square $=14.55$, $\mathrm{Pr}=0.0125$ ) suggests that the cohort effects are correlated to the regressors and that the random effect estimator is not consistent. The fixed effect model is appropriate for explaining the variation in exchangeable $\mathrm{K}$. The only variable with significant and positive effect is time trend, suggesting a positive effect of technological and management change on $\mathrm{K}$ availability. The value of rho suggests that $44 \%$ of the variance in exchangeable $\mathrm{K}$ is due to differences in cohorts' specific effects. The least square dummy variable model (LSDV) was run to get the particular effect of each cohort. A positive elasticity suggests an increase of $\mathrm{K}$ availability due to specific characteristics of that cohort.

\subsection{Analyses of Benefits and Costs of SOM Improvement through Green Manure}

Benefits due to an increase of SOM were estimated only in terms of reductions of $\mathrm{N}$ fertilizer required. A positive elasticity of SOM with respect to $\mathrm{P}$ and $\mathrm{K}$ was also found, but not statistically significant, and therefore no cost savings were estimated for these nutrients. Benefits must cover the costs of SOM improvement via green manure.

The mean $\mathrm{N}$ content was 1.0 g per kg of soil. Applying Equation (5a) to the basis situation with a soil $\mathrm{N}$ content of $0.1 \%$ results in a $\mathrm{N}$ fertilizer requirement of $38.2 \mathrm{~kg} \cdot \mathrm{ha}^{-1}$. If $17.8 \mathrm{~kg}$ of $\mathrm{N}$ fertilizer can be saved due to green manure, the requirement decreases to $20.40 \mathrm{~kg} \cdot \mathrm{ha}^{-1}$. Applying again Equation (5a) it can be seen that this requirement corresponds to a total soil $\mathrm{N}$ content of 2.0 g per $\mathrm{kg}$, which means an increase of $100 \%$ relative to the original soil $\mathrm{N}$ content. The elasticity of $\mathrm{N}$ with respect to SOM from the random effect model is 0.75 . This 
means an increase of $133 \%$ of SOM is required from the green manure to achieve a $\mathrm{N}$ content of $2 \mathrm{~g}$ per $\mathrm{kg}$. So, SOM content would have to rise from $1.55 \%$ to $3.61 \%$.

\section{Discussion}

Fixed and random effect models allow incorporating unobserved cohort (units of observation) effects such as location specific conditions, management strategies, farmers' skills or preferences, which are not included as regressors. Strategies to improve fertilizers management have to account for those particular characteristics of farmers and local conditions.

Factors influencing the availability of N, P, K were searched from literature [4] [47] [49]-[51]. Those factors for which data were available were included in the models as explanatory variables.

The significant $\mathrm{N}$ elasticity with respect to SOM of 0.75 obtained in the random effect model is consistent with the results found in the work of [52]. By applying a two-stage least square regression to evaluate determinants of soil quality, a positive and significant elasticity of 0.65 of $\mathrm{N}$ with respect to SOM was found.

Costs of growing green manure were estimated at 140 US\$ per ha. However, this may vary depending on the cost of seeds and the number of irrigations.

We estimated that mean SOM content will have to increase by $20.6 \mathrm{~g}$ per $\mathrm{kg}$ of soil to reach a break-even situation, i.e. benefits and costs of green manure are equal. Such an increase of SOM via green manure is hardly found in literature. [41] got a total increase of SOM of $6 \mathrm{~g}$ per $\mathrm{kg}$ of soil in a 4-year experiment of green manure crops. [53] reported a SOM increase of $5 \mathrm{~g}$ per $\mathrm{kg}$ of soil from green manure after 13 years in a cash crops rotation. [54] report increases of SOM between 0 and $10 \mathrm{~g}$ per $\mathrm{kg}$ of soil following green manure application in short-term experiments.

It is worth mentioning here that a soil $\mathrm{N}$ content of $2 \mathrm{~g}$ per $\mathrm{kg}$ represents a high value for tobacco production [50]. Values higher than $1.8 \mathrm{~g}$ per kg may produce problems on leaves maturity and on the final quality of tobacco [43]. Assuming a maximum target of $1.7 \mathrm{~g}$ per $\mathrm{kg}$, green manure should provide an increase of SOM of around $107 \%$, which is still high and difficult to reach by green manure crops, according to the literature.

Only the reduction of $\mathrm{N}$ fertilizer use has been taken into account as the economic benefit of SOM improvement via green manure. However, benefits of SOM improvement may also result from the enhancement of soil aggregates, soil porosity and water infiltration, cation exchange enabling, root growth and soil biota development [4]. In addition, growing green manure crops may contribute to a reduction of weeds and plant diseases [41]. Also some green manure crops can be used partially to feed animals [42].

The integrated soil fertility management (ISFM) is an appealing approach for exploring the relation between organic resources and fertilizers. Organic and mineral inputs are needed in the long term to sustain soil fertility and crop production in tropic soils. By applying organic resources to "less responsive soils" soils may be responsive to fertilizers. The application of the concept of agronomic use efficiency (incremental return to applied fertilizer and/or organic inputs) requires experiments to estimate tobacco yields in treatment where nutrients have been applied [55].

Future research would benefit from systematic surveys among farmers in the area to allow for building a real panel data set. In this way, a more precise assessment of changes over time of SOM and nutrients will be possible. In addition, it is necessary to relate soil characteristics and nutrient contents to production indicators, like tobacco yields. Also, more detailed information about management practices farmers usually apply is needed. While it is widely recognized that soils have been degraded in the Valle de Lerma, knowledge about cost-effective methods for improving SOM is still limited.

\section{Conclusions}

The average level of SOM of the pseudo panel data was low. This empirical observation indicates that there is soil degradation in the reported tobacco fields.

Pseudo panel data and panel data estimation techniques can be useful tools to establish relationships between soil characteristics and N, P and K availability in farmer's field. Specific cohorts (as proxy for farms) helped to explain differences in nutrient availability.

The random effect model gave a positive and significant elasticity of $\mathrm{N}$ with respect to SOM, which means that it is possible to increase $\mathrm{N}$ in soil with an improvement of SOM and in this way to save $\mathrm{N}$ fertilizer use. However, a large increase of SOM through green manure crops is required to realize savings in $\mathrm{N}$ fertilizer use. 
Hence, increasing SOM content through green manure appears not economically beneficial, although additional benefits may arise from green manure, which has not been accounted in this study.

\section{Acknowledgements}

The authors want to thank INTA (Instituto Nacional de Tecnología Agropecuaria) for providing the soil analysis reports for this research and for its support.

\section{References}

[1] Syers, J.K. (1997) Managing Soils for Long-Term Productivity. Philosophical Transactions of the Royal Society B: Biological Sciences, 352,1011-1021. http://dx.doi.org/10.1098/rstb.1997.0079

[2] Farquharson, R.J., Cacho, O.J., Mullen, J.D. and Schwenke, G.D. (2008) An Economic Approach to Soil Fertility Management for Wheat Production in North-Eastern Australia. Agricultural Economics, 38, 181-192. http://dx.doi.org/10.1111/j.1574-0862.2008.00292.x

[3] Wiesmeier, M., Dick, D.P., Rumpel, C., Dalmolin, R.S.D., Hilscher, A. and Knicker, H. (2009) Depletion of Soil Organic Carbon and Nitrogen under Pinustaeda Plantations in Southern Brazilian Grasslands (Campos). European Journal of Soil Science, 60, 347-359. http://dx.doi.org/10.1111/j.1365-2389.2009.01119.x

[4] Pimentel, D., Harvey, C., Resosudarmo, P., Sinclair, K., Kurz, D., McNair, M., Crist, S., Shpritz, L., Fitton, L., Saffouri, R. and Blair, R. (1995) Environmental and Economic Costs of Soil Erosion and Conservation Benefits. Science, 267, 1117-1123. http://dx.doi.org/10.1126/science.267.5201.1117

[5] Reeves, D.W. (1997) The Role of Soil Organic Matter in Maintaining Soil Quality in Continuous Cropping Systems. Soil and Tillage Research, 43, 131-167. http://dx.doi.org/10.1016/S0167-1987(97)00038-X

[6] Liu, X., Herbert, S.J., Hashemi, A.M., Zhang, X. and Ding, G. (2006) Effects of Agricultural Management on Soil Organic Matter and Carbon Transformation-A Review. Plant, Soil and Environment, 52, 531-543.

[7] Yadav, V. and Malanson, G. (2007) Progress in Soil Organic Matter Research: Litter Decomposition, Modelling, Monitoring and Sequestration. Progress in Physical Geography, 31, 131-154. http://dx.doi.org/10.1177/0309133307076478

[8] Giménez Monge, J.L., Mercado Cárdenas, G., Lacci, F., Ortega, A. and Arzeno, J.L. (2009) An Integral Approach for Tobacco Wilting. INTA-EEA Salta. Panorama Agropecuario, 52, 3-7.

[9] Carmona, P.C., Osinaga, R., Sánchez, C.D. and Arzeno, J.L. (2008) Fertilization and Population Density in Direct Planting of Creole Tobacco in Salta. XXI Argentinian Congress of Soil Science (CD), Potrero de Funes, 13-16 May 2008, 5 p. http://www.inta.gov.ar/prorenoa/zonadescarga/Sist_prod_sost/27_Carmona\%20P.pdf

[10] Arzeno, J.L. (2009) Personal Communication. Soil Degradation in the Valle de Lerma, Salta, Argentina, 131-154.

[11] Corvalán, E. (1997) Fertility Levels of Agricultural Soils in Salta. INTA-EEA Salta. Panorama Agropecuario, 50, 3438.

[12] Arzeno, J.L., Corvalán, E.R., Guardo, N. and Sánchez, C.D. (2008) Phosphorus Residual Due to Fertilization in a Soil Ustocrepte Údico of Valle de Lerma-Salta. XXI Argentinian Congress Argentino of Soil Science (CD), 13-16 May 2008, Potrero de Funes, 4 p. http://www.inta.gov.ar/prorenoa/zonadescarga/Sist_prod_sost/25_\%20Arzeno.pdf

[13] Vanlauwe, B., Aihou, K., Aman, S., Tossah, B.K., Diels, J., Lyasse, O., Hauser, S., Sanginga, N. and Merckx, R. (2000) Nitrogen and Phosphorus Uptake by Maize as Affected by Particulate Organic Matter Quality, Soil Characteristics, and Land-Use History for Soils from the West African Moist Savanna Zone. Biology and Fertility of Soils, 30, 440-449. http://dx.doi.org/10.1007/s003740050022

[14] Hatch, D.J., Joynes, A. and Stone, A. (2010) Nitrogen Uptake in Organically Managed Spring Sown Lupins and Residual Effects on Leaching and Yield of a Following Winter Cereal. Soil Use and Management, 26, 21-26. http://dx.doi.org/10.1111/j.1475-2743.2009.00252.x

[15] Segal, E., Shouse, P., Poss, J.A., Crohn, D.M. and Bradford, S.A. (2010) Recommendations for Nutrient Management Plans in a Semi-Arid Environment. Agriculture, Ecosystems \& Environment, 137, 317-328. http://dx.doi.org/10.1016/j.agee.2010.03.002

[16] Zingore, S., Manyame, C., Nyamugafata, P. and Giller, K.E. (2005) Long-Term Changes in Organic Matter of Woodland Soils Cleared for Arable Cropping in Zimbabwe. European Journal of Soil Science, 56, 727-736.

[17] Lal, R. (2009) Challenges and Opportunities in Soil Organic Matter Research. European Journal of Soil Science, 60, 158-169. http://dx.doi.org/10.1111/j.1365-2389.2008.01114.x

[18] Torquinst, C.G., Mielniczuk, J., Cerri, C.E.P. (2009) Modeling Soil Organic Carbon Dynamics in Oxisols of Ibirubá (Brazil) with the Century Model. Soil and Tillage Research, 105, 33-43. http://dx.doi.org/10.1016/j.still.2009.05.005

[19] Lal, R. (2006) Managing Soils for Feeding a Global Population of 10 Billion. Journal of the Science of Food and 
Agriculture, 86, 2273- 2284. http://dx.doi.org/10.1002/jsfa.2626

[20] Johnston, A.E., Poulton, P.R. and Coleman, K. (2009) Soil Organic Matter: Its Importance in Sustainable Agriculture and Carbon Dioxide Fluxes. Chapter 1. Advances in Agronomy, 101, 1-57. http://dx.doi.org/10.1016/S0065-2113(08)00801-8

[21] Pan, G., Smith, P. and Pan, W. (2009) The Role of Soil Organic Matter In Maintaining the Productivity and Yield Stability of Cereals in China. Agriculture, Ecosystems \& Environment, 129, 344-348. http://dx.doi.org/10.1016/j.agee.2008.10.008

[22] Yaffee, R. (2003) A Primer for Panel Data Analysis. Social Sciences, Statistics and Mapping, New York University, 10.

[23] Verbeek, M. (2004) A Guide to Modern Econometrics. Second Edition, John Wiley \& Sons, Ltd., Hoboken, 429.

[24] Inoue, A. (2008) Efficient Estimation and Inference in Linear Pseudo-Panel Data Models. Journal of Econometrics, 142, 449-466. http://dx.doi.org/10.1016/j.jeconom.2007.08.003

[25] Weis, C. and Axhausen, K.W. (2009) Induced Travel Demand: Evidence from a Pseudo Panel Data Based Structural Equations Model. Research in Transportation Economics, 25, 8-18. http://dx.doi.org/10.1016/j.retrec.2009.08.007

[26] Whitaker, J.B. (2009) The Varying Impacts of Agricultural Support Programs on U.S. Farm Household Consumption. American Journal of Agricultural Economics, 91, 569-580. http://dx.doi.org/10.1111/j.1467-8276.2009.01257.x

[27] Baudino, G. (1996) Hydrogeology of Valle de Lerma, Provincia de Salta. Doctoral Thesis, National University of Salta, Salta, 166. http://www.unsa.edu.ar/natura/GBaudino/

[28] Bravo, G., Bianchi, A., Volante, J., Alderete Salas, S., Sempronii, G., Vicini, L., Fernández, M., Lipshitz, H. and Píccolo, A. (1999) Agroeconomic Regions of Argentinian Northwest. 7 p.

http://www.inta.gov.ar/prorenoa/zonadescarga/regiones agroeco/informe regiones agroec.pdf

[29] Corradini, E., Zilocchi, H., Cuesta, R., Segesso, R., Jiménez, M.L. and Musco, J.M. (2005) Characterization of Tobacco Production Sector in Argentina. Third Version. Faculty of Agricultural Sciences. Center for Advanced Studies “Jorge Gándara”. Argentinian Catholic University Santa Maria of Buenos Aires, Research Paper Series, 171. http://64.76.123.202/site/agricultura/Tabaco/03=informes/02-publicaciones/_archivos/000002-Estudios/000002-Caracteriz aci\%C3\%B3n\%20del\%20Sector\%20Tabacalero\%20Argentino/000001-Informe\%203\%C2\%BA\%20Versi\%C3\%B3n\%2 0-\%20Junio\%202005.pdf

[30] Guardo, N. (2002) Virginia Tobacco. Soil Management and Crop Fertilization. 3 p. http://www.fertilizando.com/articulos/Tabaco\%20Virginia\%20-\%20Manejo\%20y\%20Fertilizacion.asp

[31] MinAgri (2008) Ministry of Agriculture, Livestock and Fisheries. Argentina. Agriculture. Tobacco. Production and Markets. Departments Maps by Province 2006/2007. http://64.76.123.202/site/agricultura/tabaco/06=mapa\%20produccion\%20tabaco/02-mapa\%20por\%20provincia/index. php

[32] Chavez, M.D., Berentsen, P.B.M. and Oude Lansink, A.G.J.M. (2010) Creating a Typology of Tobacco Farms According to Determinants of Diversification in Valle de Lerma (Salta-Argentina). Spanish Journal of Agricultural Research, 8, 460-471. http://dx.doi.org/10.5424/sjar/2010082-1201

[33] INTA-EEA Salta (1999-2009) National Institute for Agricultural Research. Experimental Station of Salta, Laboratoy of Soil Analysis, Reports of Farms Soil Analysis.

[34] Huidobro, J. (2009) Personal Communication. Soil Properties and Soil Analysis Interpretation. Experimental Station of Salta (INTA).

[35] Princeton University (2012) Panel Data. http://dss.princeton.edu/online_help/stats_packages/stata/panel.htm www.nyu.edu/its/pubs/connect/fall03/yafee primer.html

[36] Ortega, A. and Corvalán, E. (1992) Diagnosis of Soils. INTA-EEA Salta. Panorama Agropecuario, 42, 26-29.

[37] Greene, W.H. (2002) Econometric Analysis. 5th Edition, Prentice Hall, Upper Saddle River, 802.

[38] Baum, C.F. (2006) An Introduction to Modern Econometrics Using Stata. Stata Press, College Station, 341.

[39] Torres-Reyna, O. (2010) Panel Data Analysis. Fixed and Random Effects. Online Training Section-DSS at Princeton University. http://dss.princeton.edu/training/Panel101.pdf

[40] StataCorp (2007) Stata Statistical Software: Release 10. StataCorp LP, College Station, TX.

[41] Hamza, M.A. and Anderson, W.K. (2010) Potential and Limitations of Soil Organic Matter Build-Up in Dry Areas. African Journal of Agricultural Research, 5, 2850-2861.

[42] Vorano, A. (2007) Crops as Green Manure for Tobacco. INTA Editions, EEA Salta, 4.

[43] Fernández de Ulivarri, D. (1990) The Cultivation of Blonde Tobacco. National Institute of Agricultural Technology (INTA). Regional Center Salta-Jujuy, EEA Salta-INTA, Bulletin 1, 80. 
[44] Coprotab (2010) Cooperative of Tobacco Farmers of Salta. Price of Fertilizer, Salta.

[45] Valdez Naval, G. and Galli, J. (2008) Green Manure Report. Project "Production and Sustainable Management in VallesTemplados of Salta and Jujuy”. National Institute of Agricultural Technology, Project Report, 10.

[46] Chandra Sekhara Rao, A. and Subba Rao, I.V. (1991) Investigations on Crop Responses to Applied Phosphorus in Semi-Arid Vertisols of India. Fertilizer Research, 28, 31-40. http://dx.doi.org/10.1007/BF01048853

[47] Attumi, A.A., Barthakur, N.N., Bajgai, T.R. and Hashinaga, F. (1999) Phosphorous and Sodium Distributions in Soybean Plants Subjected to Salt Stress. Journal of the Japanese Society for Horticultural Science, 68, 746-752. http://dx.doi.org/10.2503/jjshs.68.746

[48] Corvalán, E. (2012) Personal Communication. Phosphorous Decrease in Soils of Valle de Lerma, Experimental Station of Salta (INTA).

[49] Hofman, G. and Van Cleemput, O. (2004) Soil and Plant Nitrogen. International Fertilizer Industry Association, Paris, 49. http://www.betuco.be/compost/Soil\%20and\%20plant\%20nitrogen.pdf

[50] Ballari, M.H. (2005) Virginia Tobacco. Ecophysiological Aspects and of Nutrition under Crop Production Conditions. First Edition, 224.

[51] Troeh, F.R. and Thompson, L.M. (2005) Soils and Soil Fertility. Sixth Edition, Blackwell, Ames, Iowa, 489.

[52] Tan, S.H. (2005) Land Fragmentation and Rice Production: A Case Study of Small Farms in Jiangxi Province, P.R. China. PhD Thesis, Wageningen University, Wageningen, 175.

[53] Hsu, C.P., Hu, T.L. and Lin, C.F. (2009) A Dynamic Model Assisted Evaluation on the Effects of Organic Matter Application after Changing Land Use to Paddy-Upland Rotation. Geoderma, 153, 241-253. http://dx.doi.org/10.1016/j.geoderma.2009.08.013

[54] Cherr, C.M., Scholberg, J.M.S. and McSorley, R. (2006) Green Manure Approaches to Crop Production: A Synthesis. Agronomy Journal, 98, 302-319. http://dx.doi.org/10.2134/agronj2005.0035

[55] Vanlauwe, B., Bationo, A., Chianu, J., Giller, K.E., Merckx, R., Mokwunye, U., Hiokpehai, O., Pypers, P., Tabo, R., Shepherd, K.D., Smaling, E.M.A., Woomer, P.L. and Sanginga, N. (2010) Integrated Soil Fertility Management. Operational Definition and Consequences for Implementation and Dissemination. Outlook on Agriculture, 39, 17-24. http://dx.doi.org/10.5367/000000010791169998

\section{Appendix}

Table A1. Number of cohorts by textural class and department.

\begin{tabular}{|c|c|c|c|c|c|c|c|c|}
\hline Department & Clay loam & Loam & Sandy loam & Silty loam & Silty clay loam & Clay & Cohorts & Observe \\
\hline Cerrillos & $\begin{array}{l}1(\mathrm{n}=5) \\
1(\mathrm{n}=2)\end{array}$ & $\begin{array}{l}1(\mathrm{n}=6) \\
1(\mathrm{n}=4) \\
5(\mathrm{n}=3) \\
7(\mathrm{n}=2)\end{array}$ & $\begin{array}{l}2(\mathrm{n}=3) \\
4(\mathrm{n}=2)\end{array}$ & $1(n=4)$ & $\begin{array}{l}1(\mathrm{n}=3) \\
1(\mathrm{n}=2)\end{array}$ & $1(\mathrm{n}=2)$ & 26 & 71 \\
\hline $\begin{array}{l}\text { Rosario de } \\
\text { Lerma }\end{array}$ & $\begin{array}{l}1(n=3) \\
1(n=2)\end{array}$ & $\begin{array}{l}1(\mathrm{n}=5) \\
3(\mathrm{n}=3) \\
6(\mathrm{n}=2)\end{array}$ & $\begin{array}{l}2(\mathrm{n}=3) \\
2(\mathrm{n}=2)\end{array}$ & $1(\mathrm{n}=3)$ & & & 17 & 44 \\
\hline Chicoana & $\begin{array}{l}1(\mathrm{n}=3) \\
2(\mathrm{n}=2)\end{array}$ & $\begin{array}{l}1(\mathrm{n}=5) \\
3(\mathrm{n}=4) \\
5(\mathrm{n}=3) \\
6(\mathrm{n}=2)\end{array}$ & $\begin{array}{l}5(\mathrm{n}=3) \\
3(\mathrm{n}=2)\end{array}$ & $1(\mathrm{n}=3)$ & & & 27 & 75 \\
\hline
\end{tabular}

The number of observation (years) per cohort are in parenthesis. 
Scientific Research Publishing (SCIRP) is one of the largest Open Access journal publishers. It is currently publishing more than 200 open access, online, peer-reviewed journals covering a wide range of academic disciplines. SCIRP serves the worldwide academic communities and contributes to the progress and application of science with its publication.

Other selected journals from SCIRP are listed as below. Submit your manuscript to us via either submit@scirp.org or Online Submission Portal.
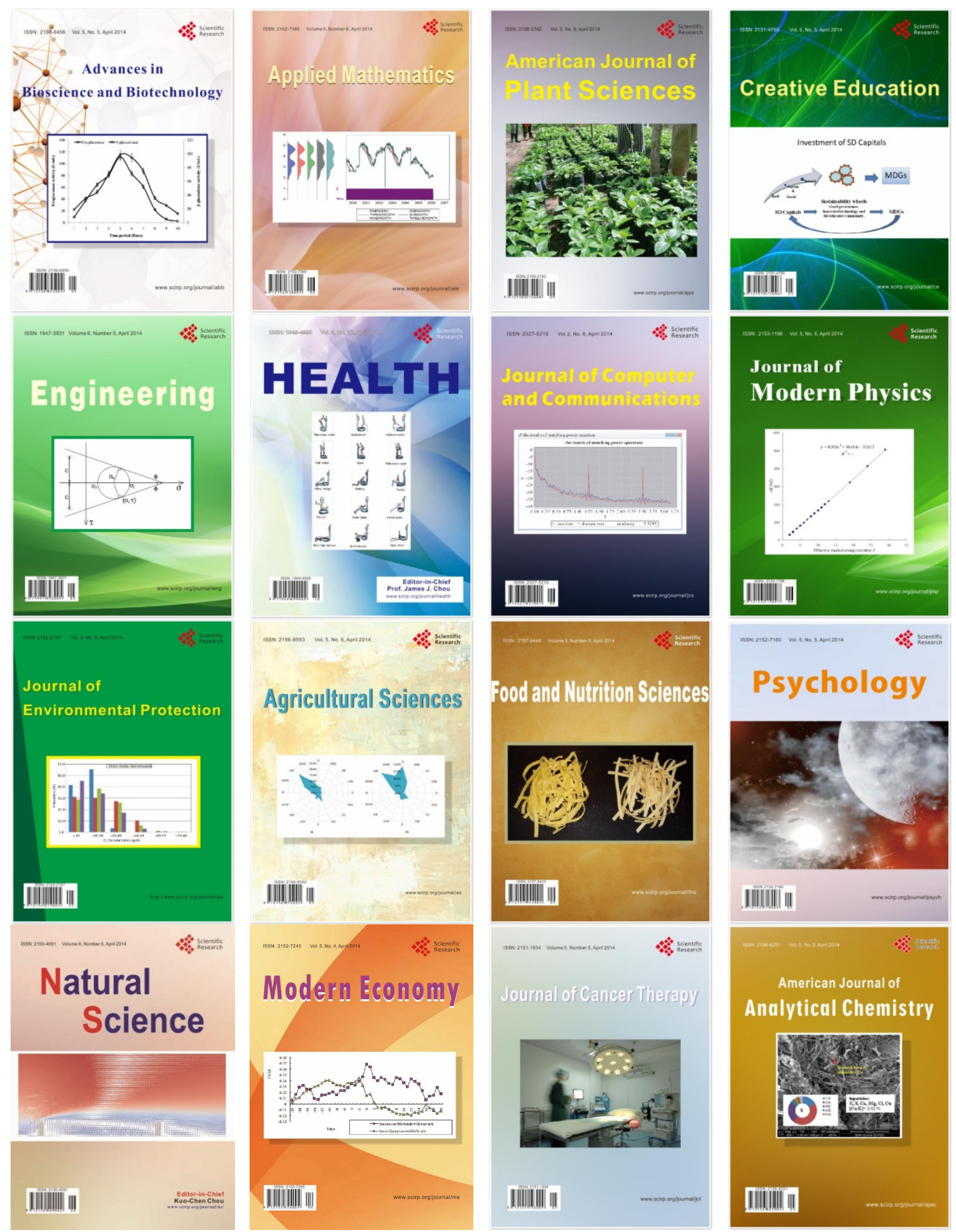